\title{
KOMPONEN KURIKULUM PENDIDIKAN AGAMA ISLAM (PAI) (ANTARA TEORI DAN PRAKTEK)
}

\author{
Nanang Budianto \\ Dosen Tetap Institut Agama Islam Al Falah As Sunniyyah (INAIFAS) \\ Kencong Jember
}

\begin{abstract}
The role of the education curriculum in terms of any aspect is very urgent. This is related to the process of scientific transformation from the older generation to the younger generation. It is fitting for the curriculum to be evaluated to be able to adjust to the demands of the times that continue to go into the era of progress both scientifically and the creativity of various thoughts that often clash with religious values. The curriculum component must consist of at least four components, namely goals, materials, methods, and evaluations. Another thing that must be considered again is that from year to year the curriculum will continue to change according to changes and developments in human thought. But how to overcome these changes, this is very dependent on the accuracy of the curriculum developer itself. One thing that must and must be considered is how Islamic education institutions can anticipate this problem, without forgetting the essence of the teachings of Islam itself.
\end{abstract}

Keyword: Basic Concepts, Components and Curriculum Philosophy

\section{PENDAHULUAN}

Dalam dunia pendidikan perencanaan dan pengarahan anak didik dalam menapaki jenjang pendidikan sangatlah urgen. Hal ini terkait dengan tuntutan masyarakat modern yang senantiasa mengikuti arah kemajuan. Salah satu komponen dalam usaha melayani tuntutan masyarakat tersebut adalah kurikulum yang sesuai dengan iklim kehidupan masyarakat konsumen pendidikan. Kurikulum secara etimologi berasal dari bahasa Yunani kuno. Curriculum dalam bahasa Yunani berasal dari kata curir, artinya pelari; dan Curere artinya tempat berpacu. Curriculum diartikan "jarak" yang harus "ditempuh" oleh pelari. Mengambil makna yang terkandung dari rumusan di atas, kurikulum dalam pendidikan diartikan sejumlah mata pelajaran yang harus ditempuh/diselesaikan anak didik untuk memperoleh ijazah. Dapat diartikan secara sederhana kurikulum adalah segala pengalaman anak di sekolah di bawah bimbingan sekolah ${ }^{1}$.

\footnotetext{
${ }^{1}$ Oemar Hamalik, Pengembangan Kurikulum (Dasar-Dasar dan Pengembangannya), (Bandung : Mandar Maju, hal. 1990).
}

FalAsIfA, Vol. 9 Nomor 2 September $2018 \mid 151$ 
Kurikulum merupakan alat atau kunci dalam prosess pendidikan formal. Tidak mengherankan apabila alat ini selalu dirombak atau ditinjau kembalii untuk mengikuti perkembangan ilmu pengetahuan dan zaman. Oleh sebab itu kurikulum juga harus selalu berkembang. Istilah pengembangan menunjuk pada suatu kegiatan menghasilkan suatu alat atau cara baru, dimana selama kegiatan tersebut penilaian dan penyempurnaan terhadap alat atau cara tersebut terus dilakukan. Bila setelah mengalami penyempurnaan penyempurnaan akhirnya alat atau cara tersebut dipandang cukup mantap untuk digunakan seterusnya, maka berakhirlah kegiatan pengembangan tersebut. Kegiatan pengembangan kurikulum mencakup penyusunan kurikulum itu sendiri, pelaksanaan di sekolah-sekolah yang disertai dengan penilaian intensif.

Di dalam makalah ini akan di bahas mengenai komponen- komponen dalam kurikulum dan pengembangan komponen-komponen tersebut dalam kurikulum PAI. Kurikulum merupakan salah satu komponen yang sangat menentukan dalam suatu sistem pendidikan, karena itu kurikulum merupakan alat untuk mencapai tujuan pendidikan dan sekaligus sebagai pedoman dalam pelaksanaan pengajaran pada semua jenis dan tingkat pendidikan.

Setiap pendidik harus memahami perkembangan kurikulum, karena merupakan suatu formulasi pedagogis yang paling penting dalam konteks pendidikan, dalam kurikulum akan tergambar bagaimana usaha yang dilakukan membantu siswa dalam mengembangkan potensinya berupa fisik, intelektual, emosional, dan sosial keagamaan dan lain sebagainya.Dengan memahami kurikulum, para pendidik dapat memilih dan menentukan tujuan pembelajaran, methode, tekhnik, media pengajaran, dan alat evaluasi pengajaran yang sesuai dan tepat. Untuk itu, dalam melakukan kajian terhadap keberhasilan sistem pendidikan ditentukan oleh semua pihak, sarana dan organisasi yang baik, intensitas pekerjaan yang realistis tinggi dan kurikulum yang tepat guna. Oleh karena itu, sudah sewajarnya para pendidik dan tenaga kependidikan bidang pendidikan Islam memahami kurikulum serta berusaha mengembangkannya. Di dalam makalah ini akan di bahas mengenai konsep dasar, komponen dan filosofi kurikulum Pendidikan Agama Islam (PAI).

\section{PEMBAHASAN}

\section{Konsep Dasar Kurikulum PAI}

Kurikulum merupakan salah satu komponen yang sangat menentukan dalam suatu sistem pendidikan, karena ia merupakan alat untuk mencapai tujuan pendidikan dan sekaligus sebagai pedoman dalam pelaksanaan pengajaran pada semua tingkatan pendidikan. 
M. Arifin memandang kurikulum sebagai seluruh bahan pelajaran yang harus disajikan dalam proses kependidikan dalam suatu sistem institusional pendidikan ${ }^{2}$.

S. Nasution menyatakan, ada beberapa penafsiran lain tentang kurikulum. Diantaranya: Pertama, kurikulum sebagai produk (hasil pengembangan kurikulum), Kedua, kurikulum sebagai hal-hal yang diharapkan akan dipelajari oleh siswa (sikap, keterampilan tertentu), dan Ketiga, kurikulum dipandang sebagai pengalaman siswa ${ }^{3}$.

Pengertian kurikulum dalam pandangan modern merupakan program pendidikan yang disediakan oleh sekolah yang tidak hanya sebatas bidang studi dan kegiatan belajarnya saja, akan tetapi meliputi segala sesuatu yang dapat mempengaruhi perkembangan dan pembentukan pribadi siswa sesuai dengan tujuan pendidikan yang diharapkan sehingga dapat meningkatkan mutu kehidupannya yang pelaksanaannya tidak hanya di sekolah tetapi juga di luar sekolah ${ }^{4}$.

Jika diaplikasikan dalam kurikulum pendidikan Islam, maka kurikulum berfungsi sebagai pedoman yang digunakan oleh pendidik untuk membimbing peserta didiknya ke arah tujuan tertinggi pendidikan Islam, melalui akumulasi sejumlah pengetahuan, keterampilan dan sikap. Dalam hal ini proses pendidikan Islam bukanlah suatu proses yang dapat dilakukan secara serampangan, tetapi hendaknya mengacu kepada konseptualisasi manusia paripurna (insan kamil) yang strateginya telah tersusun secara sistematis dalam kurikulum pendidikan Islam ${ }^{5}$.

Kurikulum dalam pendidikan Islam, dikenal dengan kata manhaj yang berarti jalan yang terang yang dilalui oleh pendidik bersama anak didiknya untuk mengembangkan pengetahuan, keterampilan, dan sikap mereka ${ }^{6}$. Selain itu, kurikulum juga dapat dipandang sebagai suatu program pendidikan yang direncanakan dan dilaksanakan untuk mencapai pendidikan ${ }^{7}$.

Pendidikan Islam yang berfalsafah al-Qur'an sebagai sumber utamanya, menjadikan al-Qur'an sebagai sumber utama penyusunan kurikulumnya. Di

${ }^{2}$ HM, Arifin, Ilmu Pendidikan Islam, (Jakarta: Bumi Aksara, 1991), hal. 183.

${ }^{3}$ S.Nasution, Asas-asas Kurikulum, (Jakarta: Bumi Aksara,1994), Cet.I, hal. 5 - 9

${ }^{4}$ H. Ramayulis, Ilmu Pendidikan Islam, (Jakarta: Kalam Mulia, 2006), Cet. Ke-5, hal. 152

${ }^{5}$ Ibid., 167.

${ }^{6}$ Omar Mohammad Al-Toumy A-Syaibany, Falsafah Pendidikan Islam, (Terj. Hassan Langgulung), (Jakarta: Bulan Bintang, 1984), hal. 478.

${ }^{7}$ Zakiyah Daradjat, dkk, Ilmu Pendidikan Islam, (Jakarta: Bumi Aksara, 1996), Cet.ke-3, hal. 122.

FaLASIFA, Vol. 9 Nomor 2 September $2018 \mid 153$ 
dalam al-Qur'an dan Hadits ditemukan kerangka dasar dan dapat dijadikan sebagai pedoman dan penyusunan kurikulum Pendidikan Islam. Kerangka dasar tersebut adalah ${ }^{8}$ :

a. Tauhid

Sesuai dengan al-Qur'an bahwa yang menjadi kurikulum inti (Intra Curiculer) Pendidikan Islam adalah 'Tauhid' dan harus dimantapkan sebagai unsur pokok yang tidak dapat dirubah. Dalam al-Qur'an Allah menyatakan sifat tauhid sebagai berikut" 'Dialah Allah Yang Esa, Allah tempat memohon, Dialah tak berputra, tak beribu Bapak, dan tiada satu pun menyamai-Nya' (QS. AlIkhlas: 1-4).

b. Iqro'

Kurikulum inti (Intra Curiculer) selanjutnya adalah perintah 'membaca' ayatayat Allah yang meliputi 3 macam ayat, yaitu: 1. Ayat Allah yang berdasarkan wahyu, 2. Ayat Allah yang ada pada diri manusia 3. Ayat Allah yang terdapat di dalam semesta di luar diri manusia. Ketiga ayat tersebut terdapat dalam (QS. Al-Alaq: 1-5) :

Sedangkan menurut Armai Arief, yang dimaksud dasar-dasar kurikulum pendidikan Islam antara lain adalah :

1) Dasar Agama

Kurikulum diharapkan dapat menolong siswa untuk membina iman yang kuat, teguh terhadap ajaran agama, beraklak mulia dan melengkapinya dengan ilmu yang bermanfaat di dunia dan akhirat

2) Dasar Falsafah

Pendidikan Islam harus berdasarkan wahyu Tuhan dan tuntutan Nabi SAW serta warisan para ulama.

3) Dasar Psikologis

Kurikulum tersebut harus sejalan dengan ciri perkembangan siswa, tahap kematangan dan semua segi perkembangannya.

4) Dasar Sosial

Kurikulum diharapkan turut serta dalam proses kemasyarakatan terhadap siswa, penyesuaian mereka dengan lingkungannya, pengetahuan dan kemahiran mereka dalam membina umat dan bangsanya ${ }^{9}$

Dasar-dasar kurikulum pendidikan Islam yang dimaksudkan di atas menurut hemat penulis adalah merupakan substansi dari content/materi

${ }^{8}$ Eneng Muslihah., Ilmu Pendidikan Islam, (Jakarta: Diadit Media, 2010), hal. 76

${ }^{9}$ Armai Arief, Pengantar Ilmu dan Metodologi Pendidikan Islam, (Jakarta: Ciputat Pers, 2002), Cet I, h. 33

154 | FaLASIFA, Vol. 9 Nomor 2 September 2018 
kurikulum itu sendiri, karena pendidikan Islam berorientasi kepada duniawi dan ukhrawi. Di dalam Islam, antara dunia dan akhirat merupakan satu kesatuan tujuan. Kehidupan dunia adalah media untuk kehidupan akhirat, sementara akhirat merupakan konsekuensi atas kualitas kehidupan dunia. Segala perbuatan muslim dalam bidang apapun memiliki kaitan dengan akhirat. Untuk itu, keempat dasar-dasar kurikulum di atas merupakan landasan atau pijakan dalam mencapai tujuan hidup di dunia dan di akhirat.

\section{Komponen Kurikulum PAI}

Komponen kurikulum secara umum dalam dunia pendidikan yang luas menurut Syaodih Sukmadinata teridentifikasi dalam unsur atau komponenen dalam anatomi tubuh kurikulum ${ }^{10}$. Komponen tersebut terdiri dari bagian-bagian sebagai berikut yaitu tujuan, isi atau materi, proses atau sistem penyampaian serta medianya, dan evaluasi, yang mana keempatnya berkaitan erat satu dengan lainnya ${ }^{11}$. Hampir sama menurut Hamid Syarief walaupun terjadi sedikit perbedaan istilah telah diuraikan tentang kurikulum secara struktural terbagi menjadi beberapa komponen di antaranya adalah tujuan kurikulum, komponen isi/bahan, komponen strategi pelaksanaan, dan komponen evaluasi ${ }^{12}$.

Dari pemaparan tersebut maka dapat disimpulkan komponen kurikulum setidaknya harus terdiri dari empat komponen yaitu tujuan, materi, metode, dan evaluasi. Oleh karena itu dari pembahasan sebelumnya tentang pembelajaran PAI maka khusus untuk kurikulum PAI di dalamnya harus bermuatan nilai-nilai ajaran Islam pada setiap komponen secara integral sehingga digambarkan sebagaimana gambar berikut ini :

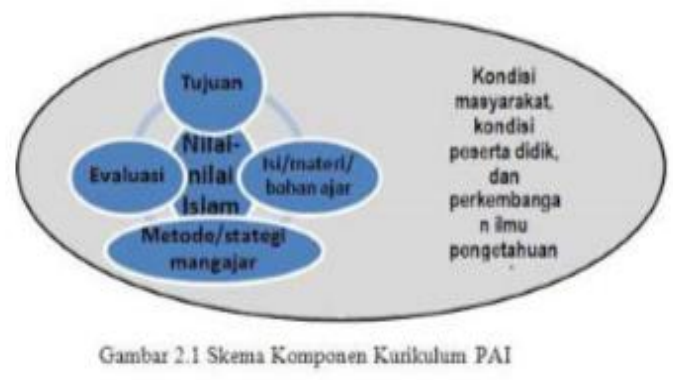

${ }^{10}$ Penggunaan kata anatomi kurikulum juga digunakan dalam artikel ilmiah. Lihat Heman Hudojo, "Tolok Ukur dan Sistem Evaluasi Terbadap Keberbasilan Pengajaran Pendidikan Agama Islam di Perguruan Tinggi," dalam Dinamika Pemikiran Islam di Perguruan Tinggi, ed. Fuaduddin \& Cik Hasan Bisri (Jakarta: Logos Wacana Ilmu, 1999), h. 184.

${ }^{11}$ Nana Syaodih Sukmadinata, Pengembangan Kurikulum: Teori dan Praktek (Bandung, Remaja Rosdakarya, 2002), hal. 102

${ }^{12}$ A. Hamid Syarief, Pengembangan Kurikulum (Surabaya: Bina Ilmu, 1996), hal. 79

FalASIFA, Vol. 9 Nomor 2 September 2018 | 155 
Dari gambar di atas jika dikaitkan pada pembahasan sebelumnya maka dapat disimpulkan komponen kurukulum PAI satu sama lain terjadi hubungan dan keterkaitan sebagai bentuk kerjasama dalam perwujudan kurikulum PAI agar tetap relevan dengan realitas, waktu, kondisi masyarakat, kondisi peserta didik, dan kondisi perkembangan ilmu pengetahuan serta teknologi. Namun yang perlu ditekankan adalah pada kurikulum PAI harus ditanamkan nilai-nilai Islam sebagai sumbu utama yang menjadi ciri khas. Walaupun demikian pendidik tetap berupaya dalam pengembangan kurikulum terutama pada materi PAI agar sistem pembelajaran PAI tetap menarik terutama bagi mahasiswa yang memiliki nalar kritis. Dengan demikian dapat ditarik garis lurus bahwa salah satu komponen dari sistem pembelajaran PAI adalah kurikulum PAI yang juga terdiri dari beberapa komponen lain yaitu tujuan, materi, metode, dan evaluasi. Sedangkan komponen lain dari sistem pembelajaran PAI adalah pendidik, peserta didik, pengelola lembaga, dan sumber pembelajaran selain pendidik.

Untuk lebih jelasnya yang dimaksud dari ke empat komponen kurikulum tersebut sebagaimana dalam uraian berikut ini :

\section{a. Tujuan}

Dalam kurikulum pendidikan dasar dan menengah dikenal katagori tujuan sebagai berikut :

1) Tujuan pendidikan nasional Tujuan pendidikan nasional merupakan, tujuan jangka panjang, tujuan ideal pendidikan bangsa Indonesia. Tujuan pendidikan di Indonesia sebagaimana tercantum dalam Undang-undang RI tahun 2003 tentang sistem Pendidikan Nasional pada Bab II Pasal 3 Yaitu: "Pendidikan Nasional berfungsi mengembangkan kemampuan dan membentuk watak serta peradaban bangsa yang bermartabat dalam rangka mencerdaskan kehidupan bangsa, bertujuan untuk berkembangnya potensi peserta didik agar menjadi manusia yang beriman dan bertaqwa kepada Tuhan Yang Maha Esa, berakhlak mulia, sehat, berilmu, cakap, kreatif, mandiri, dan menjadi warga negara yang demokratis serta bertanggungjawab ${ }^{13}$.

2) Tujuan Institusional (Tujuan Lembaga/ satuan Pendidikan)

Adalah tujuan yang diharapkan, yang dicapai oleh suatu lembaga Pendidikan, misalnya tujuan pendidikan tingkat SD, SLTP, SMU, SMK, PT.

3) Tujuan Kurikuler/Tujuan Pengajaran (Tujuan mata Pelajaran)

${ }^{13}$ Sekretariat Negara RI, Undang-undang RI No 20 tentang sistem Pendidikan Nasional, 2003.

156 | FaLASIFA, Vol. 9 Nomor 2 September 2018 
Adalah penjabaran dari Tujuan Institusional yang berisi programprogram pendidikan yang menjadi sasaran suatu bidang study atau mata kuliah, misalnya : tujuan mata pelajaran Agama, matematika Bahasa Indonesia.

Komponen Tujuan, merupakan salah satu komponen yang sangat penting dalam pengembangan kurikulum. Sebab setiap rencana harus memiliki tujuan agar dapat ditentukan apa yang harus dicapai, serta apa yang harus dilakukan untuk mencapai tujuan tersebut. Komponen Tujuan, merupakan salah satu komponen yang sangat penting dalam pengembangan kurikulum. Sebab setiap rencana harus memiliki tujuan agar dapat ditentukan apa yang harus dicapai, serta apa yang harus dilakukan untuk mencapai tujuan tersebut.

Tujuan pendidikan Islam memiliki perbedaan dengan tujuan pendidikan lain, misalnya tujuan pendidikan menurut paham pragmatisme, yang menitik beratkan pemanfaatan hidup manusia didunia. Yang menjadi standar ukurannya sangat relatif, yang bergantung pada kebudayaan atau peradaban manusia. Rumusan tujuan pendidikan Islam sangatlah relefan dengan rumusan tujuan pendidikan nasional. Dan jika dihubungkan dengan filsalafat Islam, maka kurikulumnya tentu mesti menyatu (integral) dengan ajaran Islam itu sendiri. Tujuan yang akan dicapai kurikulum PAI ialah membentuk anak didik menjadi berakhlak mulia, dalam hubungannya dengan hakikat penciptaan manusia. Sehubungan dengan kurikulum pendidikan Islam ini, dalam penafsiran luas, kurikulumnya berisi materi untuk pendidikan seumur hidup.

Pendidikan agama Islam merupakan usaha sadar dan terencana dalam menyiapkan peserta didik dalam meyakini, memahami, menghayati, dan mengamalkan ajaran Islam melalui kegiatan bimbingan, pengajaran dan pelatihan.

Maka secara garis besar (umum) tujuan pendidikan agama Islam ialah untuk meningkatkan keimanan, pemahaman, penghayatan, dan pengamalan siswa terhadap ajaran agama Islam, sehingga ia menjadi manusia muslim yang bertakwa kepada Allah SWT, serta berakhlak mulia baik dalam kehidupan pribadi, bermasyrakat, berbangsa dan bernegara. Tujuan tersebut tetap berorientasi pada tujuan penyebutan nasional yang terdapat dalam UU RI. No. 20 tahun 2003.

Selanjutnya tujuan umum PAI diatas dijabarkan pada tujuan masingmasing lembaga pendidikan sesuai dengan jenjang pendidikan yang ada. Selain itu, pendidikan agama Islam sebagai sebuah program pembelajaran yang diarahkan untuk :

FaLASIFA, Vol. 9 Nomor 2 September 2018 | 157 
Nanang Budianto

1) Menjaga akidah dan ketaqwaan peserta didik.

2) Menjadi landasan untuk lebih rajin mempelajari dan mendalami ilmu-ilmu agama.

3) Mendorong peserta didik untuk lebih kritis, kreatif, dan inovatif.

4) Menjadi landasan prilaku dalam kehidupan sehari-hari dimasyarakat.

Dengan demikian bukan hanya mengajarkan pengetahuan secara teori semata tetapi juga untuk dipraktekkan atau diamalkan dalam kehidupan sehari-hari (membangun etika sosial) ${ }^{14}$.

b. Materi

Isi/materi kurikulum pada hakekatnya adalah semua kegiatan dan pengalaman yang dikembangkan dan disusun dalam rangka mencapai tujuan pendidikan ${ }^{15}$. Isi kurikulum atau pengajaran bukan hanya terdiri atas sekumpulan pengetahuan atau kumpulan informasi, tapi harus merupakan kesatuan pengetahuan terpilih dan dibutuhkan bagi pengetahuan baik bagi pengetahuan itu sendiri, maupun siswa dan lingkungannya ${ }^{16}$.

Ada dua hal yang harus diperhatikan ketika membicarakan isi kurikulum. Pertama, isi kurikulum didefinikan sebagai bahan atau materi belajar dan mengajar. Bahan itu tidak hanya berisikan informasi factual, tetapi juga mencakup pengetahuan, ketrampilan, konsep-konsep, sikap dan nilai. Kedua, dalam proses belajar mengajar, dua elemen kurikulum yaitu isi dan methode, berinteraksi secara konstan. Isi memberikan signifikansi jika ditransmisikan kepada anak didik dalam beberapa hal dan cara, dan itulah yang disebut metode atau pengalaman belajar mengajar. Hubungann antara isi dan metode sangatlah dekat, tetapi keduanya dipisahkan menjadi elemen-elemen kurikulum, masing-masing dapat dinilai dengan criteria yang berbeda. Baik isi maupun metode harus signifikan sehingga hasil dari belajar efektif bisa diraih dengan baik ${ }^{17}$.

Secara umum, isi kurikulum itu dapat dikelompokkan menjadi 3 bagian, yaitu :

a. Logika, yaitu pengetahuan tentang benar-salah, berdasarkan prosedur

${ }^{14}$ Hamdan, Pengembangan dan Pembinanaan Kurikulum (Teori dan Praktek Kurikulum PAI), (Banjarmasin, 2009), hal. 40.

${ }_{15}$ Zainal Arifin, Komponen dan Organisasi Kurikulum (Bandung : PT Remaja Rosdakarya, 2011), hal. 88.

16 Nana Syaudih Sukmadinata, Pengembangan Kurikulum Teori \& Praktik, (Bandung : Remaja Rosdakarya, 1997), hal. 127.

17 Abdullah Idi, Pengembangan Kurikulum Teori \& Praktik (Jogjakarta : Ar Ruz Media, 2011), hal. 211-212

158 | FaLASIFA, Vol. 9 Nomor 2 September 2018 

keilmuan,

b. Etika, yaitu pengetahuan tentang baik-buruk, nilai dan moral,

c. Estetika, yaitu pengetahuan tentang indah-jelek, yang ada nilai seni ${ }^{18}$.

Berdasarkan pengelompokan isi kurikulum tersebut, maka pengembangan isi kurikulum harus disusun berdasarkan prinsip-prinsip sebagai berikut : 1

a. Mengandung bahan kajian / topic yang dapat dipelajari peserta didik dan dalam proses pembelajaran,

b. Berorientasi pada standart komptensi lulusan, standart kompetensi mata pelajaran dan kompetensi dasar yang telah ditetapkan ${ }^{19}$.

\section{c. Metode}

Metode atau strategi merupakan komponen ketiga dalam pengembangan kurikulum. Komponen ini merupakan komponen yang memiliki peran sangat penting, sebab berhubungan dengan implementasi kurikulum. Strategi merujuk pada pendekatan dan metode serta peralatan mengajar yang digunakan dalam pengajaran. Tetapi pada hakikatnya strategi pengajaran tidak hanya terbatas pada hal itu saja. Pembicaraan strategi pengajaran tergambar dari cara yang ditempuh dalam melaksanakan pengajaan, mengadakan penilaian, pelaksanaan bimbingan dan mengatur kegiatan, baik yang secara umum berlaku maupun yang bersifat khusus dalam pengajaran. Metode atau strategi pelaksanaan kurikulum berhubungan dengan bagaimana kurikulum itu dilaksanakan disekolah. Kurikulum merupakan rencana, ide, harapan, yang harus diwujudkan secara nyata disekolah, sehingga mampu mampu mengantarkan anak didik mencapai tujuan pendidikan. Kurikulum yang baik tidak akan mencapai hasil yang maksimal, jika pelaksanaannya menghasilkan sesuatu yang baik bagi anak didik. Komponen strategi pelaksanaan kurikulum meliputi pengajaran, penilaian, bimbingan dan penyuluhan dan pengaturan kegiatan sekolah ${ }^{20}$.

Metode dan perangkat kegiatan yang direncanakan untuk mencapai tujuan tertentu. Strategi pembelajaran merupakan rencana tindakan (rangkaian kegiatan) termasuk penggunaan metode dan pemanfaatan berbagai sumber daya / kekuatan dalam pembelajaran. Upaya untuk mengimplementasikan rencana yang sudah disusun dalam kegiatan nyata agar tujuan yang telah disusun tercapai secara optimal, dinamakan metode.

Metode pembelajaran yang berorientasi pada guru tersebut mendapat

${ }^{18}$ Zainal Arifin, Komponen dan Organisasi Kurikulum, hal. 88.

${ }^{19}$ Ibid., hal. 88-89.

20 Hamid syarif. Pengembanagan kurikulum (Pasuruan: garoeda buana indah, 1993), hal. 108

FalASIFA, Vol. 9 Nomor 2 September 2018 | 159 
reaksi dari kalangan progresivisme. Menurut kalangan progresivisme, yang seharusnya aktif dalam suatu proses pembelajaran adalah peserta didik itu sendiri. Peserta didik secara aktif menentukan materi dan tujuan belajarnya sesuai dengan minat dan kebutuhannya, sekaligus menentukan bagaimana cara-cara yang paling sesuai untuk memperoleh materi dan mencapai tujuan belajarnya. Pembelajaran yang berpusat pada peserta didik mendapat dukungan dari kalangan rekonstruktivisme yang menekankan pentingnya proses pembelajaran melalui dinamika kelompok.

Pembelajaran cenderung bersifat kontekstual, metode dan teknik pembelajaran yang digunakan tidak lagi dalam bentuk penyajian dari guru tetapi lebih bersifat individual, langsung, dan memanfaatkan proses dinamika kelompok (kooperatif), seperti; pembelajaran moduler, obeservasi, simulasi atau role playing, diskusi, dan sejenisnya. Selanjutnya, dengan munculnya pembelajaran berbasis teknologi yang menekankan pentingnya penguasaan kompetensi membawa implikasi tersendiri dalam penentuan strategi pembelajaran. Meski masih bersifat penguasaan materi atau kompetensi seperti dalam pendekatan klasik, tetapi dalam pembelajaran teknologis masih dimungkinkan bagi peserta didik untuk belajar secara individual.

\section{d. Evaluasi}

Evaluasi merupakan salah satu komponen kurikulum. Dalam pengertian terbatas, evaluasi kurikulum dimaksudkan untuk memeriksa tingkat ketercapaian tujuan-tujuan pendidikan yang ingin diwujudkan melalui kurikulum yang bersangkutan ${ }^{21}$. Sedangkan dalam pengertian yang lebih luas, evaluasi kurikulum dimaksudkan untuk memeriksa kinerja kurikulum secara keseluruhan ditinjau dari berbagai kriteria. Indikator kinerja yang dievaluasi tidak hanya terbatas pada efektivitas saja, namun juga relevansi, efisiensi, kelaikan (feasibility) program ${ }^{22}$.

Evaluasi kurikulum memegang peranan penting, baik untuk penentuan kebijakan pendidikan pada umumnya maupun untuk pengambilan keputusan dalam kurikulum itu sendiri. Hasil-hasil evaluasi kurikulum dapat digunakan oleh para pemegang kebijakan pendidikan dan para pengembang kurikulum dalam memilih dan menetapkan kebijakan pengembangan sistem pendidikan dan pengembangan model kurikulum yang digunakan.

Hasil-hasil evaluasi kurikulum juga dapat digunakan oleh guruguru,

${ }^{21}$ Abdullah Idi, Pengembangan Kurikulum Teori \& Praktik (Jogjakarta : Ar Ruz Media, 2011), hal. 219.

${ }^{22}$ Hamid syarif. Pengembanagan kurikulum (Pasuruan: garoeda buana indah, 1993), hal. 112.

160 | FaLASIFA, Vol. 9 Nomor 2 September 2018 
kepala sekolah dan para pelaksana pendidikan lainnya dalam memahami dan membantu perkembangan peserta didik, memilih bahan pelajaran, memilih metode dan alat-alat bantu pelajaran, cara penilaian serta fasilitas pendidikan lainnya.

\section{e. Filosofi Kurikulum PAI}

Filsafat berasal dari kata Yunani kuno, yaitu dari kata "philos" dan "Sophia". Philos, artinya cinta yang mendalam dan Sophia adalah kearifan atau kebijaksanaan ${ }^{23}$. Secara harfiah filosofis (filsafat) berarti "cinta akan kebijaksanaan”24. Asas filosofis dalam penyusuna kurikulum berarti bahwa penyusunan kurikulum hendaknya berdasar dan terarah pada falsafat bangsa yang dianut. Filsafat berasal dari bahasa yunani Philoshopis, philo, philos, pholein yang berarti cinta, pecinta, mencintai, sedang shopia berarti kebijaksanaan, wisdom, kearifan, hikmat, hakikat kebenaran ${ }^{25}$. Filsafat dapat diartikan sebagai pegangan atau pandangan hidup. Filsafat juga berarti sekumpulan sikap dan kepercayaan terhadap kehidupan alam yang biasa diterima secara kritis. Atau suatu proses kritik atau pemikiran terhadap kepercayaan dan sikap yang kita junjung tinggi, usaha untuk mendapatkan gambaran secara keseluruhan, analisa logis dari bahasan, serta penjelasan tentang arti kata dan konsep. Ada pula yang berpendapat bahwa filsafat merupakan sekumpulan problema yang langsung mendapat perhatian dari manusia, dan dicari jawabannya, suatu cara hidup yang konkret, suatu pandangan hidup yang total tentang manusia dan alam, atau merupakan perenungan terhadap hakikat sesuatu secara universal, radikal, dan spekulatif dengan menggunakan kemampuan optimal akal manusia.

Filsafat memegang peranan penting dalam pengembangan kuikulum. Sama halnya seperti dalam Filsafat Pendidikan, kita dikenalkan pada berbagai aliran filsafat, seperti : perenialisme, essensialisme, eksistesialisme, progresivisme, dan rekonstruktivisme. Dalam pengembangan kurikulum pun senantiasa berpijak pada aliran - aliran filsafat tertentu, sehingga akan mewarnai terhadap konsep dan implementasi kurikulum yang dikembangkan. Dengan merujuk kepada pemikiran Ella Yulaelawati (2003), di bawah ini diuraikan tentang isi dari-dari masing-masing aliran filsafat, kaitannya dengan pengembangan kurikulum :

\footnotetext{
${ }^{23}$ Wina Sanjaya. Kurikulum dan Pembelajaran, Jakarta: Kencana, 2009, hal 70.

${ }^{24}$ Nana Syaodih Sukmadinata, Pengembangan Kurikulum" Teori dan Praktek, Bandung: PT. Remaja Rosdakarya, 2002, hal.39

${ }^{25}$ H. Dakir, Perencanaan dan Pengembangan Kurikulum, Jakarta: PT. Rineka Cipta, 2004 , hal. 72
}

FALASIFA, Vol. 9 Nomor 2 September $2018 \mid 161$ 
1) Perenialisme lebih menekankan pada keabadian, keidealan, kebenaran dan keindahan dari pada warisan budaya dan dampak sosial tertentu. Pengetahuan dianggap lebih penting dan kurang memperhatikan kegiatan sehari-hari. Pendidikan yang menganut faham ini menekankan pada kebenaran absolut, kebenaran universal yang tidak terikat pada tempat dan waktu. Aliran ini lebih berorientasi ke masa lalu.

2) Essensialisme menekankan pentingnya pewarisan budaya dan pemberian pengetahuan dan keterampilan pada peserta didik agar dapat menjadi anggota masyarakat yang berguna. Matematika, sains dan mata pelajaran lainnya dianggap sebagai dasar-dasar substansi kurikulum yang berharga untuk hidup di masyarakat. Sama halnya dengan perenialisme, essesialisme juga lebih berorientasi pada masa lalu.

3) Eksistensialisme menekankan pada individu sebagai sumber pengetahuan tentang hidup dan makna. Untuk memahami kehidupan seseorang mesti memahami dirinya sendiri. Aliran ini mempertanyakan : bagaimana saya hidup di dunia ? Apa pengalaman itu?

4) Progresivisme menekankan pada pentingnya melayani perbedaan individual, berpusat pada peserta didik, variasi pengalaman belajar dan proses. Progresivisme merupakan landasan bagi pengembangan belajar peserta didik aktif.

5) Rekonstruktivisme merupakan elaborasi lanjut dari aliran progresivisme. Pada rekonstruktivisme, peradaban manusia masa depan sangat ditekankan. Di samping menekankan tentang perbedaan individual seperti pada progresivisme, rekonstruktivisme lebih jauh menekankan tentang pemecahan masalah, berfikir kritis dan sejenisnya. Aliran ini akan mempertanyakan untuk apa berfikir kritis, memecahkan masalah, dan melakukan sesuatu ? Penganut aliran ini menekankan pada hasil belajar dari pada proses ${ }^{26}$.

Aliran Filsafat Perenialisme, Essensialisme, Eksistensialisme merupakan aliran filsafat yang mendasari terhadap pengembangan Model Kurikulum Subjek-Akademis. Sedangkan, filsafat progresivisme memberikan dasar bagi pengembangan Model Kurikulum Pendidikan Pribadi. Sementara,

26 E. Mulyasa, Kurikulum Berbasis Kompetensi. Konsep; Karakteristik dan Implementasi. (Bandung : PT. Remaja Rosdakarya, 2003), hal. 5.3

162 | FalASIFA, Vol. 9 Nomor 2 September 2018 
filsafat rekonstruktivisme banyak diterapkan dalam pengembangan Model Kurikulum Interaksional.

Masing-masing aliran filsafat pasti memiliki kelemahan dan keunggulan tersendiri. Oleh karena itu, dalam praktek pengembangan kurikulum, penerapan aliran filsafat cenderung dilakukan secara eklektif untuk lebih mengkompromikan dan mengakomodasikan berbagai kepentingan yang terkait dengan pendidikan. Meskipun demikian saat ini, pada beberapa negara dan khususnya di Indonesia, tampaknya mulai terjadi pergeseran landasan dalam pengembangan kurikulum, yaitu dengan lebih menitikberatkan pada filsafat rekonstruktivisme.

Dapat disimpulkan bahwa landasan filsafat merupakan dasar atau pijakan dalam melihat segala sesuatu dari sudut bagaimana seharusnya dengan fakta sebagaimana adanya sehingga bisa menjadi bahan masukan bagi manusia untuk membantu memecahkan berbagai masalah dalam kehidupan.

\section{KESIMPULAN}

Dari uraian di atas dapat kita simpulkan bahwa peranan kurikulum pendidikan ditinjau dari segi manapun sangatlah urgen. Hal ini terkait dengan proses transformasi keilmuan dari generasi tua ke generasi muda. Sudah sepatutnya kurikulum selalu dievaluasi untuk dapat menyesuaikan dengan tuntutan zaman yang terus melangkah ke era kemajuan baik secara saintific maupun kreatifitas berbagai pemikiran yang kerapkali berbenturan dengan nilai religi. Hal lain yang harus diperhatikan lagi bahwa dari tahun ke tahun kurikulum akan terus berubah sesuai dengan perubahan dan perkembangan pemikiran manusia. Namun bagaimana cara mengatasi perubahan tersebut, hal ini sangat tergantung kepada kecermatan pengembang kurikulum itu sendiri. Satu hal yang harus dan mesti diperhatikan adalah bagaimana lembaga pendidikan Islam dapat mengantisipasi masalah ini, tanpa melupakan esensi ajaran-ajaran agama Islam itu sendiri.

\section{DAFTAR PUSTAKA}

A.Hamid Syarief, Pengembangan Kurikulum, Surabaya: Bina Ilmu, 1996.

Armai Arief, Pengantar Ilmu dan Metodologi Pendidikan Islam, Jakarta: Ciputat Pers, 2002.

Abdullah Idi, Pengembangan Kurikulum Teori \& Praktik, Jogjakarta : Ar Ruz Media, 2011.

Dakir, Perencanaan dan Pengembangan Kurikulum, Jakarta: PT. Rineka Cipta, 2004.

FalASIFA, Vol. 9 Nomor 2 September 2018 | 163 
Nanang Budianto

E. Mulyasa, Kurikulum Berbasis Kompetensi. Konsep; Karakteristik dan Implementasi, Bandung : PT. Remaja Rosdakarya, 2003.

Eneng Muslihah, Ilmu Pendidikan Islam, Jakarta: Diadit Media, 2010.

HM. Arifin, HM., Ilmu Pendidikan Islam, Jakarta: Bumi Aksara, 1991.

Hamid Syarif, Pengembangan Kurikulum, Pasuruan: Garoeda Buana Indah, 1993.

Hamdan, Pengembangan dan Pembinanaan Kurikulum (Teori dan Praktek Kurikulum PAI), Banjarmasin, 2009.

Nana Syaodih Sukmadinata, Pengembangan Kurikulum: Teori dan Praktek, Bandung, Remaja Rosdakarya, 2002.

Omar Mohammad Al-Taoumy Syaibany, Falsafah Pendidikan Islam, Terj.Hassan Langgulung, Jakarta: Bulan Bintang, 1984.

Oemar Hamalik, Pengembangan Kurikulum (Dasar-Dasar dan Pengembangannya), Bandung : Mandar Maju, 1990.

Ramayulis, Ilmu Pendidikan Islam, Jakarta: Kalam Mulia, 2006.

S. Nasution, Asas-asas Kurikulum, Jakarta: Bumi Aksara,1994.

Undang-undang RI Nomor 23, Tentang Sistem Pendidikan Nasional, 2003.

Wina Sanjaya, Kurikulum dan Pembelajaran, Jakarta: Kencana, 2009.

Zakiyah Daradjat dkk, Ilmu Pendidikan Islam, Jakarta: Bumi Aksara, 1996.

Zainal Arifin, Komponen dan Organisasi Kurikulum, Bandung : PT Remaja Rosdakarya, 2011. 